ро н лізов но клім тичні пок зники по трьох метеост нціях у верхів'ї б сейну р. рут і їхній вплив н розвиток суч сних рельєфоутворюв льних процесів у меж х цієї території. етеорологічні д ні взято зі снігол винної ст нції кр їни ожижевськ (висот - 1433 м), відомчої метеост нції (висот - 978 м) орногірського геогр фічного ст ціон ру ьвівського н ціон льного університету імені в н $\mathrm{p}$ нк і селестокової ст нції в м. ремч (висот - 530 м). ереп д висот між метеост нціями ст новить 903 м. сновним з вд нням було з'ясув ти зміни певних клім тичних х р ктеристик і перебігу екзогенних процесів н різних гіпсометричних рівнях у верхів'ї б сейну р. рут.

лючові слов : темпер тур повітря, безморозний період, сніговий покрив, ш р оп дів.

о н йпоширеніших рельєфоутворюв льних процесів, які формують суч сну морфоскульптуру орногірського р йону, н леж ть ерозійно- кумулятивн діяльність річок, площинний змив, ярков ерозія, обв льно-осипні, зсувні, дефлюкційні т селеві процеси. озвитку суч сних екзогенних процесів сприяє морфологічн поясність і висотн ярусність [4]. етеост нції, д ні яких про н лізов но, розт шов ні н різних гіпсометричних рівнях, які відрізняються між собою н бором суч сних екзогенних процесів, с ме: снігол винн ст нція іністерств н дзвич йних ситу цій кр їни ( ) ожижевськ, відомчої метеост нції орногірського геогр фічного ст ціон ру ьвівського н ціон льного університету імені в н р нK ( ) т селестокової ст нції м. ремч .

еред усіх клім тичних х р ктеристик, які вплив ють н розвиток екзогенних процесів, н н шу думку, н йбільше зн чення м ють х р ктеристики темпер турного режиму, режиму тмосферних оп дів, висот снігового покриву і з п си води в ньому. ому с ме ці х р ктеристики бр ли до ув ги.

ередньорічн темпер тур повітря по кожній з метеост нцій т іï екстрем льні зн чення $з$ рік виявили цілком з кономірні пок зники, с ме: середньорічн темпер тур повітря з період 2007-2010 рр. знижув л сь від 8,5 ${ }^{\circ} \mathrm{C}$ м. ремч до 5,5 ( ) - 3,8 ${ }^{\circ} \mathrm{C}$ ожижевськ , що свідчить про зниження темпер тури повітря з висотою. кстрем льні (дод тні й від’ємні) зн чення цього пок зник з період 2007-2010 рр. колив лись у досить високих меж х: від $30^{\circ}$ (2007) до - $24^{\circ}$ (2010) ( ). трьох метеост нцій н йекстрем льнішим цей пок зник виявився для

одо середньої трив лості безморозного періоду в повітрі (бр ли до ув ги всі дод тні зн чення темпер тури повітря, тобто зн чення темпер тури повітря, які не переходили через $0^{\circ}$ ) з період 2007-2010 рр. по двох метеост нціях, то н йдовше він три-

(с) удич ., н тяк ., 2012 
в в 2008 р. - ожижевськ 210 дні, 229 днів; н йкоротшим безморозний період для ожижевськ був у 2010 р. - 166 днів, для - у 2009 році - 200 днів (т бл. 1,2) [7, 8].

ередня трив лість безморозного періоду, дні

блиця 1

\begin{tabular}{|c|c|c|c|c|}
\hline \multirow{2}{*}{ етеост нції } & \multicolumn{4}{|c|}{ оки } \\
\cline { 2 - 5 } & 2007 & 2008 & 2009 & 2010 \\
\hline & 228 & 229 & 200 & 215 \\
\hline & 178 & 210 & 199 & 166 \\
\hline
\end{tabular}

блиця 2

ередня трив лість безморозного періоду з відлиг ми, дні

\begin{tabular}{|c|c|c|c|c|}
\hline \multirow{2}{*}{ етеост нції } & \multicolumn{4}{|c|}{ оки } \\
\cline { 2 - 5 } & 2007 & 2008 & 2009 & 2010 \\
\hline & 137 & 137 & 165 & 150 \\
\hline & 187 & 156 & 166 & 199 \\
\hline
\end{tabular}

ерші від’ємні середньодобові зн чення темпер тури повітря н метеост нціях у верхів'ї руту спостеріг ють у середньому в другій дек ді жовтня. Зн чимо, що для ожижевськ д т н ст ння перших від'ємних зн чень темпер тури повітря $є$ доволі нестійкою і з фіксов н н йр ніше у першій дек ді жовтня (2010), н йпізніше у третій дек ді листоп д (2008). тійкий перехід темпер тури повітря через 0 в околицях простежується перев жно у першій дек ді грудня, у високогір'ї (

ожижевськ ) - від першої дек ди листоп д по першу дек ду грудня. ередня темпер тур січня в м. ремч 3 цей період (2007-2010) колив л сь у меж х від 3,4 у 2007 р. до $-6,5{ }^{\circ} \mathrm{C}$ у 2010 р. і ст новил $1,7{ }^{\circ} \mathrm{C}$. е с ме зн чення н i

ожижевськ колив лось у меж х від $0,5^{\circ} \mathrm{C}$ у 2007 р. до $-6,9^{\circ} \mathrm{C}$ у 2010 р. ( ) і від $-3,9^{\circ}$ у 2008 р. до $-7^{\circ}$ у 2010 p. ( ожижевськ ) т ст новило, відповідно, -4,3 і $-5,3{ }^{\circ} \mathrm{C}$ (т бл. 3) [7-9]. ередня темпер тур липня в м. ремч 3 цей період бул в меж х від $17,1{ }^{\circ} \mathrm{C}$ у 2008 р. до $19^{\circ} \mathrm{C}$ і ст новил $18,2{ }^{\circ} \mathrm{C}$. е с ме зн чення н i ожижевськ в меж х від $14,8^{\circ}$ у 2008 р. до $-15,9^{\circ}$ у 2010 р. ( ) і від $12,3^{\circ}$ у 2008 р. до $-14,3^{\circ}$ у 2007 p. ( ожижевськ ) і ст новило, відповідно, 15,3 і 13,6 ${ }^{\circ}$, що свідчить про зниження темпер тури повітря з підняттям уверх (т бл. 3) [7-9].

блиця 3

ередні зн чення темпер тури повітря н йтеплішого і н йхолоднішого місяців

(2007-2010), ${ }^{\circ} \mathrm{C}$

\begin{tabular}{|c|c|c|}
\hline \multirow{2}{*}{ етеост нції } & \multicolumn{2}{|c|}{ ередня темпер тур } \\
\cline { 2 - 3 } & січня & липня \\
\hline м. ремч & 1,7 & 18,2 \\
\hline & $-4,3$ & 15,3 \\
\hline ожижевськ & $-5,3$ & 13,6 \\
\hline
\end{tabular}


олив ння темпер тури повітря зн чно вплив ють н розвиток екзогенних процесів, які поширені в меж х цієї території. прикл д, добові контр сти темпер тур, 3 мерз ння і розмерз ння н сиченого водою грунту сприяє розвитку гр віт ційних процесів. скелястих виступ х у високогір'ї формуються обв ли, рухливішими ст ють к м'яні розсипи (утворюються в р зі виходів н поверхню твердих порід), які легко підд ються фізичному звітрюв нню. орногорі к м’яні розсипи є н уркулі, рецкулі, пицях, ізл х т інших вершин х біля виходів пісковиків і конгломер тів чорногірської серії відкл дів. бв ли формуються н дуже крутих схил х і стінк х к рів т ніш, сформов них н виход х “голів” твердих пл стів зворотного щодо схилу п діння.

кими є більшість схилів північно-східної експозиції в приполонинській ч стині хребт орногор [6].

тійкий сніговий покрив формується кожного року. ількість днів зі сніговим покривом з період 2007-2010 рр. ст новил : м. ремч -90, -157, ожижевськ - 160 дні. т бл. 4-8 [7, 8] н ведено д ні про середню висоту снігового покриву і з п си води в ньому протягом 2007-2010 pp. рис. 1-4 ці д ні відобр жені у вигляді гістогр м.

блиця 4

ередня висот снігового покриву і з п си води в ньому, (2007)

\begin{tabular}{|c|c|c|c|c|c|c|c|}
\hline \multirow[t]{2}{*}{ етеост нції } & \multicolumn{7}{|c|}{ ісяці } \\
\hline & I & II & III & IV & $\mathrm{X}$ & XI & XII \\
\hline \multicolumn{8}{|c|}{ ередня висот снігового покриву, см } \\
\hline & 11 & 45 & 33 & 4 & 8 & 15 & 26 \\
\hline ожижевськ & 32 & 84 & 77 & 31 & 17 & 9 & 23 \\
\hline \multicolumn{8}{|c|}{ п си води, мм } \\
\hline & 21 & 58 & 32 & - & - & - & 21 \\
\hline ожижевськ & 148 & 462 & 402 & 257 & 51 & 65 & 142 \\
\hline
\end{tabular}

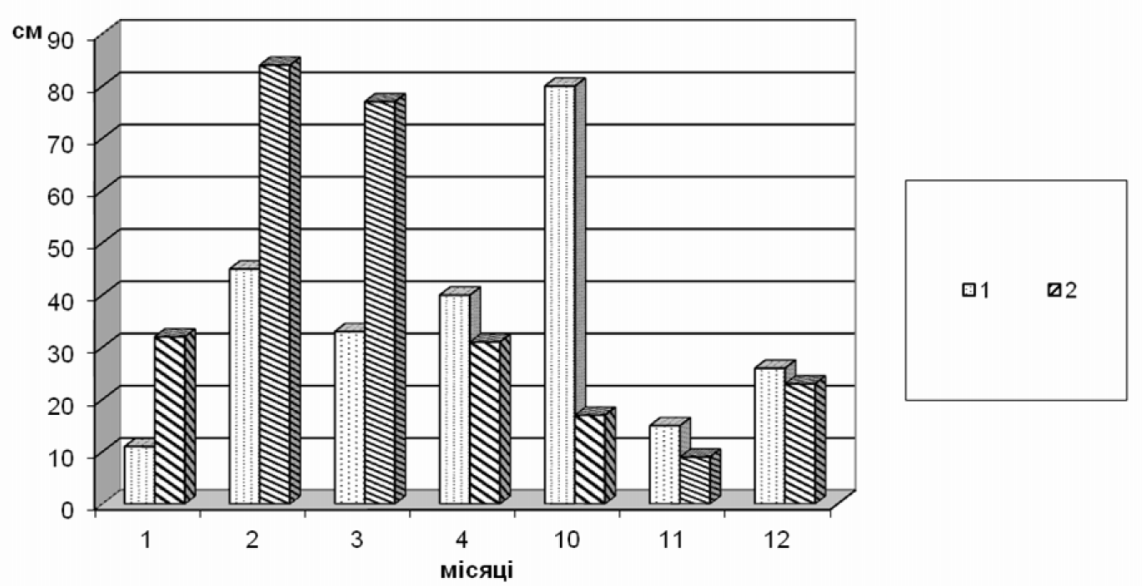

ис. 1. істогр м розподілу середньої висоти снігового покриву з 2007 р., см: 1 - ; 2 - ожижевськ . 
ередня висот снігового покриву і з п си води в ньому, (2008)

\begin{tabular}{|c|c|c|c|c|c|c|c|}
\hline \multirow[t]{2}{*}{ етеост нції } & \multicolumn{7}{|c|}{ ісяці } \\
\hline & I & II & III & IV & $\mathrm{X}$ & XI & XII \\
\hline \multicolumn{8}{|c|}{ ередня висот снігового покриву, см } \\
\hline & 34 & 40 & 43 & 22 & - & 12 & 32 \\
\hline ожижевськ & 20 & 28 & 72 & 40 & - & 23 & 22 \\
\hline \multicolumn{8}{|c|}{ П си води, мм } \\
\hline & 29 & 37 & 15 & - & - & 40 & 33 \\
\hline ожижевськ & 151 & 197 & 392 & 431 & - & 44 & 152 \\
\hline
\end{tabular}

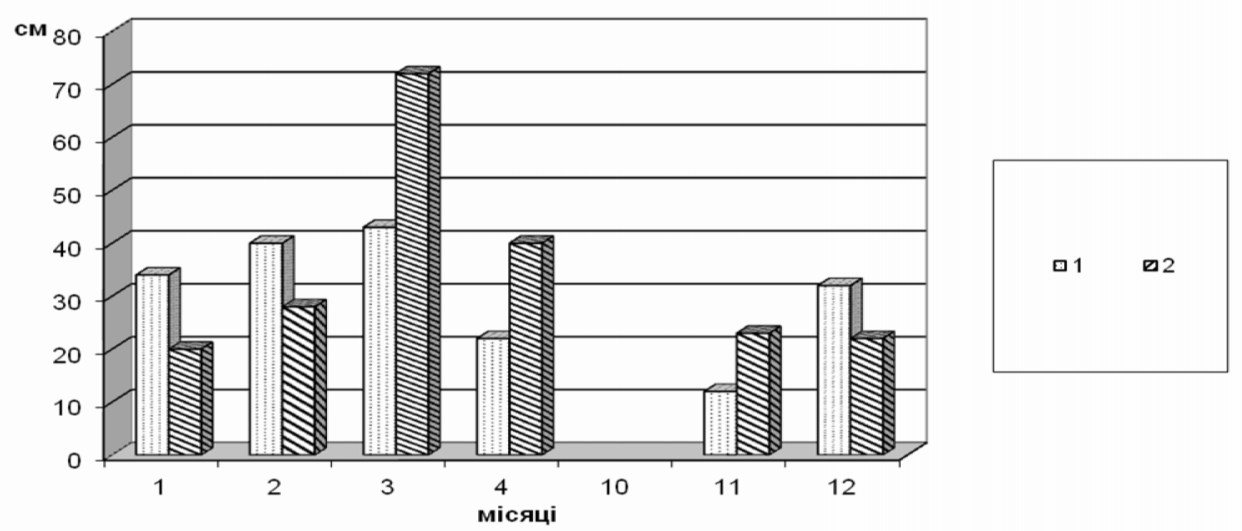

ис. 2. істогр м розподілу середньої висоти снігового покриву з 2008 р., см: 1 - ; 2 - ожижевськ .

блиця 6

ередня висот снігового покриву і з п си води в ньому (2009)

\begin{tabular}{|c|c|c|c|c|c|c|c|}
\hline \multirow{2}{*}{ етеост нції } & \multicolumn{7}{c|}{ ісяці } \\
\cline { 2 - 8 } & I & II & III & IV & X & XI & XII \\
\hline & ередня висот снігового покриву, см \\
\hline & 45 & 55 & 77 & 42 & 24 & 1 & 6 \\
\hline ожижевськ & 12 & 35 & 59 & 16 & 30 & 6 & 6 \\
\hline & 49 & 74 & 28 & - & - & - & - \\
\hline ожижевськ & 152 & 200 & 231 & - & 97 & - & 43 \\
\hline
\end{tabular}



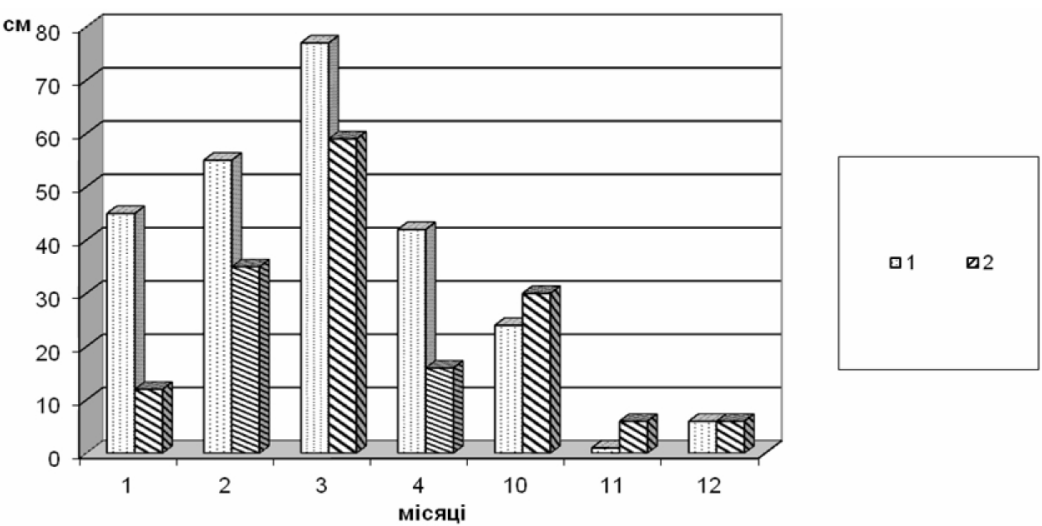

ич. 3. ' 'істогр м розподілу середньої висоти снігового покриву з 2009 р., см: 1 - ; 2 - ожижевськ .

ередня висот снігового покриву і з п си води в ньому (2010)

блиця 8

\begin{tabular}{|c|c|c|c|c|c|c|c|}
\hline \multirow[t]{2}{*}{ етеост нції } & \multicolumn{7}{|c|}{ ісяці } \\
\hline & I & II & III & IV & $\mathrm{X}$ & XI & XII \\
\hline \multicolumn{8}{|c|}{ ередня висот снігового покриву, см } \\
\hline & 19 & 28 & 43 & 3 & 7 & 8 & 16 \\
\hline ожижевськ & 35 & 38 & 43 & 6 & 3 & 2 & 11 \\
\hline \multicolumn{8}{|c|}{ п си води, мм } \\
\hline & 48 & 47 & 34 & 31 & - & - & 25 \\
\hline ожижевськ & 137 & 168 & 254 & 107 & 31 & - & 44 \\
\hline
\end{tabular}
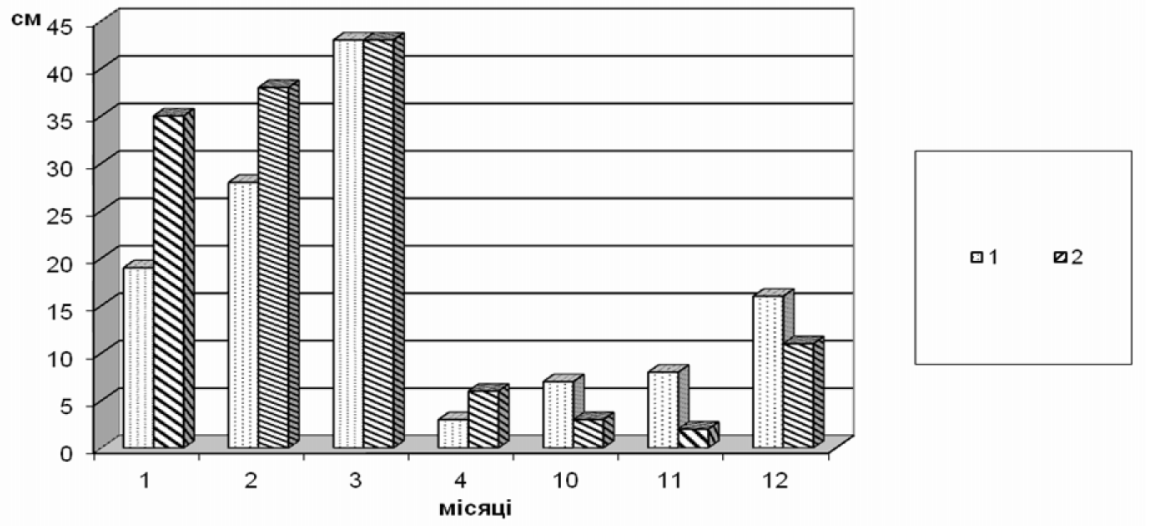

ис. 4. істогр м розподілу середньої висоти снігового покриву з 2010 р., см: 1 - ; 2 - ожижевськ . 
ксим льн висот снігового покриву (2007-2010), см

блиця 9

\begin{tabular}{|r|c|c|c|c|c|c|c|c|}
\hline \multirow{2}{*}{ оки } & \multirow{2}{*}{ етеост нції } & \multicolumn{6}{|c|}{ ісяці } \\
\cline { 2 - 8 } & & I & II & III & IV & X & ХI & ХІІ \\
\hline \multirow{2}{*}{2007} & 35 & 65 & 45 & 18 & 17 & 27 & 46 \\
\cline { 2 - 9 } & ожижевськ & 59 & 101 & 95 & 61 & 22 & 22 & 43 \\
\hline \multirow{2}{*}{2008} & 55 & 52 & 63 & 45 & - & 40 & 70 \\
\cline { 2 - 9 } & & 44 & 40 & 102 & 94 & - & 55 & 49 \\
\hline \multirow{2}{*}{2009} & ожижевськ & 55 & 68 & 109 & 71 & 57 & 2 & 13 \\
\cline { 2 - 8 } & & 23 & 57 & 89 & 43 & 63 & 11 & 21 \\
\hline \multirow{2}{*}{2010} & ожижевськ & 31 & 46 & 69 & 12 & 13 & 21 & 22 \\
\cline { 2 - 8 } & & 45 & 45 & 81 & 28 & 16 & 7 & 27 \\
\hline
\end{tabular}

ерший сніговий покрив н

ожижевськ і

з'являється перев жно у другій дек ді жовтня, у другій дек ді грудня він ст є стійким. рідк стійкий сніговий покрив формується у другій дек ді листоп д -першій дек ді грудня (2008), м ксим льної висоти він досяг є у лютому-березні (т бл. 9) [7-8].

зн чимо, що потужність снігового покриву т 3 п си вологи в ньому н різних елемент х рельєфу неодн кові т головно визн чені н прямом і силою вітру в зимовий період. гребенях хребтів сніговий покрив незн чний - сильні вітри здув ють великі м си снігу в д вньольодовикові котли т улоговини. прикінці зими його потужність н окремих схил х може ст новити пон д 5, в улоговин х - до 10 м [5].

осить ч сто під ч с відлиг, ускл днених інтенсивними дощ ми, сніговий покрив повністю зник є. емпер тур повітря в січні може підвищув тись від 4,3-5,6 ( ) до 5,8-9 ${ }^{\circ} \mathrm{C}$, що пояснюють явищем темпер турної інверсії, коли н гірських хребт х темпер тур повітря є вищою, ніж у долин х, де трив лий ч с зберіг ється холодне повітря. огляду н ч сті темпер турні інверсії т відлиги сніговий покрив здебільшого б г тош ровий з різною щільністю, льодяною кіркою. ожуть сходити снігові л вини, відбув тися обв ли снігових к рнизів. ильні вітри м йже повністю здув ють сніг з безлісих схилів південної експозиції ( озьмеск, ришевськ т ін.), що спричиняе глибоке промерз ння грунту.

нігот нення з звич й почин ється з переходом середньодобових темпер тур через $0{ }^{\circ} \mathrm{C}$ і досяг є н йбільшої інтенсивності з дод тних мінім льних добових темпер тур. ого швидкість модифікується орієнт цією схилів щодо сонця, товщиною снігового покриву. кремі сніжники в ніш х т уступ х, н схил х північної експозиції зберіг ються всю весну т в літні місяці. нігот нення формує водний режим грунтів т водотоків. p зі швидкого т нення формується ктивний поверхневий стік і змив, в р зі повільного - зн чн ч стин т лої води інфільтрується в грунт т звітрені породи.

к свідч ть дослідження [1], незв ж ючи н порівняно невеликий середній з п с води у сніговому покриві, під ч с снігот нення у русл потоків стік є зн чн кількість води, оскільки мерзлий ш р грунту утворює водонепроникний горизонт. Зимку грунти у 
високогір'ї промерз ють н 60-80 см у глибину. к н слідок, коефіцієнт поверхневого стоку т лих вод є н б г то більшими, ніж під ч с стокоформув льних дощів. ксим льний змив грунту т лими вод ми, зрештою, як і ктивіз ція розвитку інших екзогенних процесів, відбув ється у роки з потужним сніговим покривом т інтенсивним снігот ненням. ідт к, конкретиз ція середніх д т поч тку руйнув ння стійкого снігового покриву т кількість днів снігот нення н був є пр ктичного зн чення. оцільним $є$ створення прогнозного блоку пок зників, прогр ми н укових спостережень і дослідних л бор торій, які б охоплюв ли дослідження п р метрів снігот нення.

рп ти розт шов ні в зоні помірного зволоження [5]. роте річні суми оп дів з лежно від висоти й експозиції схилів колив ються від 500 до 1500 мм і більше. г лом південно-з хідні схили більше зволожені, ніж північно-східні.

території досліджень протягом 2007-2010 рр. вип л т к кількість оп дів, мм: ожижевськ - 1 518-2 104, - 976-1 700, ремч - 864-1 333. вигляді дощів 3 квітень-жовтень 2007-2010 рр. у верхів’ї руту річної суми вип ло, \%: ожижевськ -59-64, -60-70, ремч -72-88 (т бл. 10, рис. 5) [7-9].

ідсотковий розподіл кількості оп дів по метеост нціях

3 квітень-жовтень 2007-2010 рр., \%

\begin{tabular}{|c|c|c|c|c|}
\hline \multirow{2}{*}{ етеост нції } & \multicolumn{4}{|c|}{ оки } \\
\cline { 2 - 5 } & 2007 & 2008 & 2009 & 2010 \\
\hline ремч & 78 & 84 & 72 & 88 \\
\hline & 61 & 68 & 60 & 70 \\
\hline ожижевськ & 59 & 64 & 60 & 64 \\
\hline
\end{tabular}
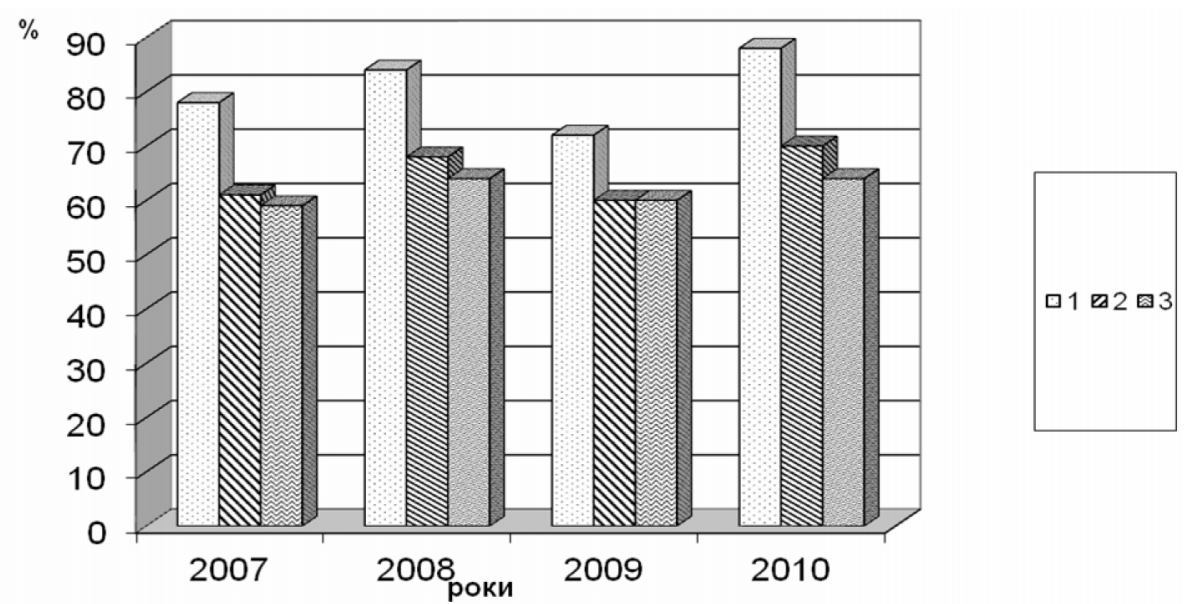

ис. 5. ідсотковий розподіл кількості оп дів по метеост нціях 3 квітень-жовтень 20072010 рр.: 1 - ремч ; 2 - ;3- ожижевськ . 
ередня кількість днів $з$ рік 3 ш ром оп дів пон д 5 мм 3 д ними метеост нцій ст новить: ожижевськ - від 96 (2009) до 132 (2010), - від 60 (2009) до 101 (2010) т колив ється в меж х 50-60 днів у м. ремч . одноч с, середня кількість днів 3 рік з ш ром оп дів пон д 20 мм т к : ожижевськ - 19-28, - 6-24, ремч - 5-20 днів. т ціон рні дослідження [1] н стокових м йд нчик х з свідчили, що 3 н явності інших умов т кий ш р оп дів може спричинюв ти поверхневий стік. мив грунту дощовими вод ми досяг є м ксим льного розвитку у літні місяці (тр вень-вересень), під ч с яких н території дослідження вип ло н ожижевськ 40-55\%, в околицях 38-60\%, у ремч 53-71\% річної суми оп дів (т бл. 11 , рис. 6) [7-9].

території досліджень з усієї кількості оп дів м йже 75 \% вип д ють злив ми [5]. ісля них водні потоки м ють велику руйнівну силу й призводять до ерозії схилів, ктивіз ції зсувних процесів (зокрем, уздовж дороги - росляк), у русл х потоків, річок відбув ється перевідкл дення люві льного м тері лу, інтенсивнішою ст є боков і донн ерозія.

блиця 11

ідсотковий розподіл кількості оп дів по метеост нціях з теплий період (тр вень-вересень) 2007-2010 рр., \%

\begin{tabular}{|c|c|c|c|c|}
\hline \multirow{2}{*}{ етеост нції } & \multicolumn{4}{|c|}{ оки } \\
\cline { 2 - 5 } & 2007 & 2008 & 2009 & 2010 \\
\hline ремч & 65 & 66 & 53 & 71 \\
\hline & 42 & 51 & 38 & 60 \\
\hline ожижевськ & 51 & 49 & 40 & 55 \\
\hline
\end{tabular}
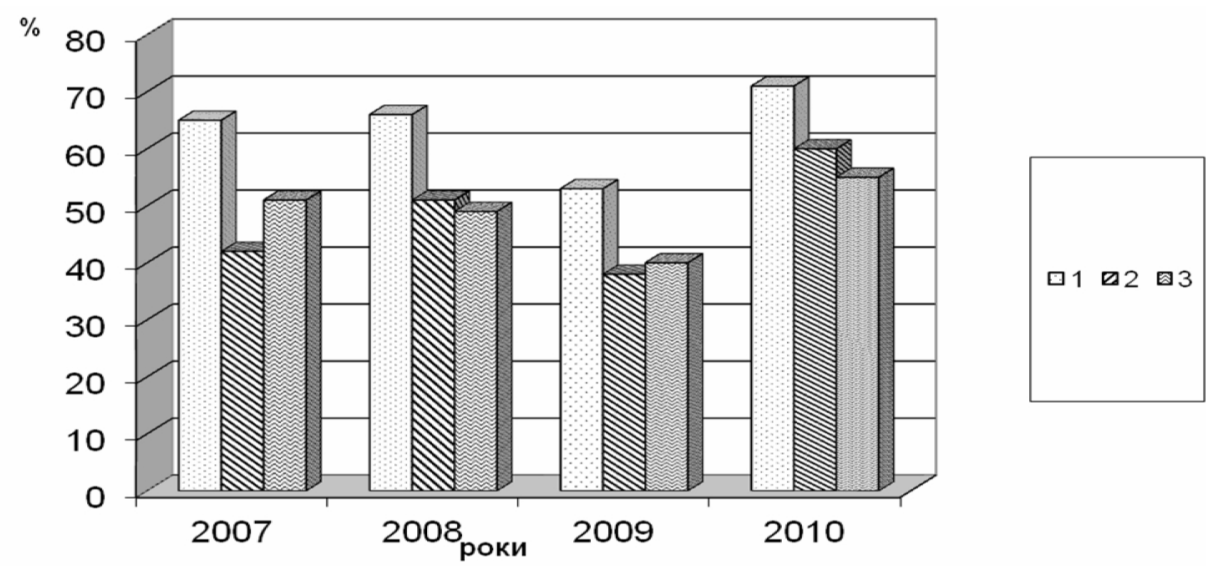

ис. 6. ідсотковий розподіл кількості оп дів по метеост нціях з теплий період (тр веньвересень) 2007-2010 рр.: 1 - ремч ;2- ;3- ожижевськ . 
кож для верхів’я 6 сейну р. рут х р ктерні ч сті п водки. весні вони зумовлені т ненням снігу, у літній період - зливовими і з тяжними дощ ми. оді може бути з топлен з пл в , відбув тись біфурк ція русл (роздвоєння н рук ви) потоку, посилюв тись донн і бічн ерозія ріки. і процеси інтенсивно відбув ються в р. рут. ідмиви і розмиви берег тут спостеріг ють у періоди повеней і п водків, коли різко збільшується к л мутність води т кількість рухливого твердого м тері лу у водній м сі, ун слідок цього н гром джується лювій т утворюються 3 пл вні й руслові поверхні, які домінують н пр вому березі ріки [2]. рикл дом цього є п водок 2008 р. під ч с якого вн слідок дощів 24-27 липня 2008 р. в меж х верхньої ч стини б сейну p. рут вип в ш р 300 мм оп дів, який сформув в поверхневий, грунтовий і русловий стік. н слідок п водк відбул ся ктивіз ція геоморфологічних процесів. онн ерозія в руслі руту в околицях орногірського геогр фічного ст ціон ру в середньому ст новил 50-60 см і спричинил розмив ння морени до корінних порід н проміжку 200 м, т кож відбул ся ктивіз ція зсувних процесів ун слідок перезволоження грунтового покриву і зниження його інфільтр ційної зд тності [3].

ротягом липня 2008-квітня 2010 рр. у русл х р. рут, т кож його приток рипору і оресик з кл дено поперечні перерізи, які д ли змогу про н лізув ти зміни в русл х цих рік, які відбулися після проходження липневого п водк 2008 р. ослідження з свідчили, що русло руту в місці з кл дення поперечного перерізу 3 (н впроти викл д цького корпусу), де 3 фіксов но зн чне відступ ння лівого берег, поглибилось у середньому н 80 см. усло потоку рипір, у якому зн чні зміни з фіксов ні в лівобережній ч стині потоку, поглибилось н 40-45см. підст ві зіст влення різноч сових поперечних перерізів потоку оресик можн ск з ти, що тільки для цього потоку х р ктерн зн чн кумуляція н носів н всьому відрізку з кл деного перерізу, проте н йбільших змін з зн л лівобережн ч стин русл, у якій потужність н носів сяг л в середньому 37 (поперечний переріз 1) і 30 см (поперечний переріз 2) [2].

езульт ти н півст ціон рних досліджень інтенсивності глибинної ерозії т кумуляції в русл х р. рут, потоків рипір і оресик з свідчили, що зн чні зміни в русл х цих рік відбулися після проходження тут липневого п водк 2008 р., який був зумовлений зн чною кількістю оп дів з м лий проміжок ч су.

ослідження клім тичних х р ктеристик у меж х певних територій т 6 сейнових систем є кту льним з огляду н їхній тісний зв'язок з розвитком суч сних екзогенних процесів. ро н лізув вши певні клім тичні х р ктеристики по трьох метеост нціях (м. ремч, , ожижевськ ), які, н н шу думку, н йбільше вплив ють н розвиток і перебіг суч сних екзогенних процесів, можн ск 3 ти, що одним із основних чинників, від якого з леж ть усі ці клім тичні х р ктеристики, є рельєф земної поверхні (переп д бсолютних висот між метеост нціями ст новить 903 м). ідомо, що 3 підняттям угору темпер тур повітря знижується, колив ння темпер тури повітря зн чно вплив $€$ н розвиток суч сних екзогенних процесів. прикл д, н скелястих виступ х у високогір'ї формуються обв ли, рухливішими ст ють к м'яні розсипи, що утворюються в р зі виходів н поверхню твердих порід, які легко підд ються фізичному звітрюв нню. ельєф т кож вплив є н розподіл т режим тмосферних оп дів, що виявляється у збільшенні кількості оп дів з підняттям угору (н ожижевськ вип д є більш кількість оп дів, ніж у м. ремч ), тому в околиця ожижевськ і ми спостеріг ємо зн чне перев ж ння гр віт ційних процесів, процесів поверхневого змиву і лінійного розмиву, бокової і донної ерозій у руслі руту, які спричинені ч стими т інтенсивнішими оп д ми в меж х цієї території. 
1. олюх . т цион рное изучение плоскостного смыв в редк рп тье / . олюх, . н ш, ит, . р вчук- ьвов : ищ школ , 1976. - . 22-30.

2. удич . езульт ти досліджень руслових процесів у верхів’ї б сейну річки рут (2008-2010) /

. удич // існ. ьвів. ун-ту. ер. геогр. -2011. - ип. 39. - . 149-166.

3. колого-геогр фічні н слідки к т строфічного п водку у липні 2008 року у верхів’ї р. рут // риродні комплекси й екосистеми верхів'я ріки рут: функціонув ння, моніторинг, охорон . ьвів : ид вничий центр ім. . р нк , 2009. - . 151-155.

4. $р$ вчук . . у уч сні екзогенні рельєфоутворюв льні процеси // еоморфологія олонинськоорногірських рп т/ . . р вчук. - ьвів : ид вничий центр ім. . p нк , 2008. .98-106.

5. естерук - лім т// ослинний світ кр їнських рп т: орногор кологічні м ндрівки / . естерук. - ьвів : , 2003. - . 20.

6. уч сні фізико-геогр фічні процеси // орногірський геогр фічний ст ціон р : н вч. посібник. - ьвів : ид вничий центр ім. . р нк , 2003. - . 88-89.

7. ондові метеорологічні д ні кр їни ожижевськ , 2007-2010 рр.

8. ондові метеорологічні д ні орногірського геогр фічного ст ціон ру ( ) ( ьвівського н ціон льного університету ім. в н р нк ), 2007-2010 pp.

9. ондові метеорологічні д ні селестокової ст нції в м. ремче, 2007-2010 pp.

m ття: н дійшл до редколегї̈02.11.2011

прийнят до друку 20.12.2011

\section{CLIMATIC FACTORS AND THEIR IMPACT ON THE DEVELOPMENT OF EXOGENOUS PROCESSES IN THE BASIN OF THE UPPER PRUT RIVER}

\section{Dudych, I. Gnatyak}

Ivan Franko National University of Lviv,

. Doroshenko St., 41, UA - 79000 Lviv, Ukraine

In this article are analyzed some climatic indicators which were taken from three meteorological stations in the basin of the upper Prut River and influence this climatic indicators on the development of modern relief-forming processes. Meteorological data taken from weather station Pozhyzhevska (altitude $1433 \mathrm{~m}$ ), Chornohora Geographical Station (altitude $978 \mathrm{~m}$ ) and weather station in Yaremcha (altitude $530 \mathrm{~m}$ ). Altitudinal magnitude between these stations is 903 meters. The main task of the study, was to clarify the changes of certain climatic characteristics and course of exogenous processes on different hypsometric levels in the basin of the upper Prut River.

Key words: air temperature, frost-free period, snow cover, precipitation layer. 


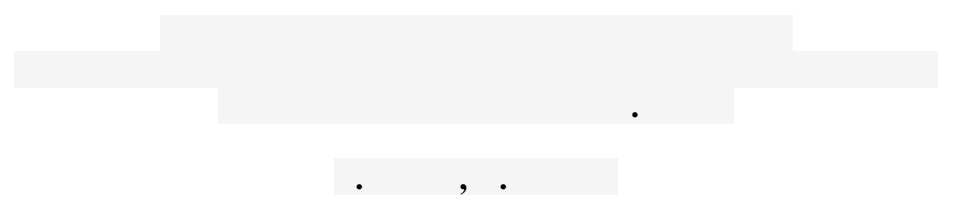

ввовский н цион льный университет имени в н

ул. . орошенко, 41, г. ьвов, 79000, кр ин

ро н лизиров но некоторые клим тические пок з тели по трем метеост нциях в верховье 6 ссейн p. рут их влияние н р звитие современных рельефоформирующих процессов в предел х этой территории. етеорологические д нные взято со снегол винной ст нции ожыжевск я (высот - 1433 м), ведомственной метеост нции (высот - 978 м) ерногорского геогр фического ст цион р ьвовского н цион льного университет имени в н ст нции в г. ремч (высот - 530 м). ереп д высот между ст нциями сост вляет 903 м. сновной $з$ д чей было выяснение изменения определенных клим тических х р ктеристик и протек ние экзогенных процессов н р зличных гипсометрических уровнях в верховье 6 ссейн p. рут.

лючевые слов : темпер тур воздух , безморозный период, снежный покров, слой ос дков. 